(C) 1989 ISIJ

/1/1/I/I/I/I/III/I

論 文

IIIIIIIIIIIIIIIII

\title{
$\mathrm{Ti}^{-} \mathrm{P}$ 添加極低炭素冷延鋼板の機械的性質に 及ぼす焼鈍温度の影響
}

$$
\text { 鄭暢 } * \text {. 鄭鎭 煥 }{ }^{* 2}
$$

\section{Effect of Annealing Temperature on the Mechanical Properties of an Extra-low Carbon Cold-rolled Steel Sheet Containing P and Ti}

Woo-Chang JEONG and Jin-Hwan CHUnG

Synopsis :

The effect of annealing temperature on the mechanical properties of extra-low carbon cold-rolled steel sheet containing $\mathrm{P}$ and $\mathrm{Ti}$ was investigated. The obtained results are as follows :

1) The observed correlation of tensile propeprties with annealing temperature is interpreted in terms of a newly proposed strengthening mechanism which differs from the previously suggested one.

2) Precipitation strengthening calculated from Ashby-Orowan model for steel sheet continuously annealed in the temperature range of $750-810^{\circ} \mathrm{C}$ for 30 seconds is about $80 \mathrm{MPa}$.

3) In extra-low carbon cold-rolled steel sheet containing $\mathrm{P}$ and $\mathrm{Ti}$, effective $\mathrm{Ti}$ content can be expressed more realistically by $\mathrm{Ti}^{* *}=$ Total $\mathrm{Ti}-(48 / 14) \mathrm{N}-(48 / 32) \mathrm{S}-\mathrm{Ti}$ as $(\mathrm{Fe}, \mathrm{Ti}) \mathrm{P}$ than by the previous equation, $\mathrm{Ti}^{*}=$ Total $\mathrm{Ti}-(48 / 14) \mathrm{N}-(48 / 32) \mathrm{S}$.

Key words : extra-low carbon steel ; cold-rolled steel sheet; continuous-annealing ; mechanical properties ; precipitation of $(\mathrm{Fe}, \mathrm{Ti}) \mathrm{P}$.

\section{1. 緒言}

自動車の車体軽量化や安全性向上を目的に薄肉化され た高強度鋼板の使用量が増加しており，その中でも主な 高強度冷延鋼板としてはりん添加 $\mathrm{Al}$ キルド鋼が内・外 板の深絞り用部品に使用されている(1)ー4). しかしフェン ダーパネルやクオーターパネルのようにりん添加鋼でも 成形が難しい部品では超深絞り用高強度冷延鋼板が用い られている5).このような用途のために開発された鋼板 は，従来の極低炭素鋼に $\mathrm{Ti}$ または $\mathrm{Nb}$ などの炭空化物 形成元素を単独あるいは複令添加したIF 鋼 (Interstitial Free Steel) に P, Si および Mnなどの固 溶強化元素を添加したもので, りん添加 $\mathrm{Al}$ キルド鋼よ り $\bar{r}$ 值㧍よび伸びが高く, 降伏強度が低いという材質 特性を有している5).
一方， P と Ti が一緒に含有された超深絞り用高強度 冷延鋼板ではりん化物，( $\mathrm{Fe}, \mathrm{Ti}) \mathrm{P}$ が多量に析出され ることが報告されているが6)，この析出物が機械的性質 におよぼす影響については詳細な検討がなされていな w.

本報では $\mathrm{P}$ と $\mathrm{Ti}$ が多量に含有された極低炭素 $\mathrm{Al}$ キ ルド鋼を素材にして $(\mathrm{Fe}, \mathrm{Ti}) \mathrm{P}$ の析出掞よび溶解挙動 を調べここの析出物による析出強化量の評価から超深絞 り用高強度冷延鋼板の機械的性質におよほす焼鈍温度の 効果を究明しようと試みた。

\section{2. 実 験 方 法}

供試鋼は真空溶製した小形鋼塊で，その化学成分を Table 1 に示す. 鋼塊は熱間鍛造により $20 \mathrm{~mm}$ 厚のス ラブにしたのち $1100^{\circ} \mathrm{C} て ゙ ~ 1 \mathrm{~h}$ 加熱後 3 パスの熱間压延

Table 1. Chemical composition of a specimen (wt \%).

\begin{tabular}{ccccccccc}
\hline $\mathrm{C}$ & $\mathrm{Si}$ & $\mathrm{Mn}$ & $\mathrm{P}$ & $\mathrm{S}$ & $\mathrm{Ti}$ & $\mathrm{N}$ & Sol. Al & Atomic ratio of $\mathrm{Ti}^{*} / \mathrm{C}$ \\
\hline 0.0042 & 0.43 & 0.63 & 0.072 & 0.0091 & 0.080 & 0.0035 & 0.054 & 3.23 \\
\hline $\mathrm{Ti}^{*}=$ Total $\mathrm{Ti}-(48 / 14) \mathrm{N}-(48 / 32) \mathrm{S}$ & & & & & &
\end{tabular}

昭和 62 年 10 月本会講演大会にて発表 将成元年 1 月 17 日受付 (Received Jan. 17, 1989)

* 産業科学技術研究所 I. 博 (Research Institute of Industrial Science \& Technology, P. O. Box 135, Pohang 790-330, Korea)

*2 産業科学技術研究所 (Research Institute of Industrial Science \& Technology) 
により $4.0 \mathrm{~mm}$ 厚の熱延板を作製した。 3 パス目の仕上 圧延温度は約 $910^{\circ} \mathrm{C}$ であり, 現場の巻取り処理をシミュ レートするために $650^{\circ} \mathrm{C}$ の炉中にて $1 \mathrm{~h}$ 保持したのち 炉冷した。熱延板は酸洗後 $0.8 \mathrm{~mm}$ 厚まで泠間圧延した のち ASTM サブサイズ（ゲージ長さ $25 \mathrm{~mm}$, 幅 6.25 $\mathrm{mm})$ の引張試験片に加工した.

すべての試料の再結晶焼鈍は赤外線加熱炉（ULVAC 社製）で行い, 加熱速度は約 $8^{\circ} \mathrm{C} / \mathrm{s}$ ，均熱は 750 $900^{\circ} \mathrm{C}$ で $40 \mathrm{~s}$, 冷却は $650^{\circ} \mathrm{C}$ までは $5^{\circ} \mathrm{C} / \mathrm{s}$, それ以下 の温度では $45^{\circ} \mathrm{C} / \mathrm{s}$ で行った。

$\mathrm{X}$-線回折試験片と再結晶温度測定用試験片の熱処理 は，烧鈍温度が $650^{\circ} \mathrm{C}$ より高い場合前と同様な熱処理 サイクルで処理したが, $650^{\circ} \mathrm{C}$ 以下の場合その温度で $30 \mathrm{~s}$ 保持したのち $45^{\circ} \mathrm{C} / \mathrm{s}$ の冷却速度で急泠を行った。

焼鈍板の引張特性は引張方向が压延方向と一致するよ

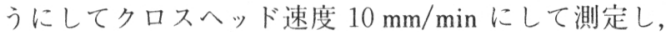
時効指数 (Aging Index, $A I$ ) は 7.5\%の予歪み付加時の 変形応力と $100^{\circ} \mathrm{C}, 1 \mathrm{~h}$ 時効処理後の下降伏応力との差 から求めた。深絞り性の指標である $r$ 值は $15 \%$ 歪みで 測定し, 平均 $r$ 值 $\left(\bar{r}\right.$ 值) は $\left(r_{0}+2 r_{45}+r_{90}\right) / 4$ より 計算した。

結晶組織は光学顕微鏡を用い, 析出物の形態は日本電 子(株)製 JEM200CX を用い加速電圧 $200 \mathrm{kV}$ にて抽出 レプリカ法によって観察した。また析出物の成分は JEM200CX に付設された EDSによって分析した.

再結晶挙動を調査するために硬さ試験は Matsuzawa Seiki 社（Model DMH-1L）の Micro-Vickers 硬度計を

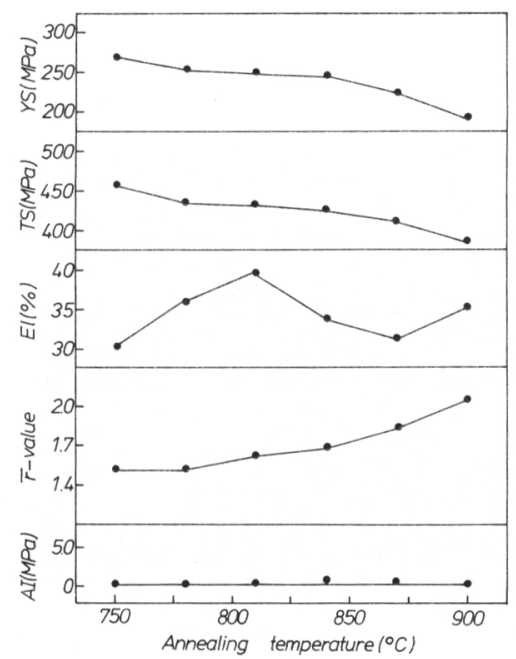

Fig. 1. Effect of annealing temperature on mechanical properties of annealed sheets.
用い荷重 $50 \mathrm{~g}$ で測定した。焼鈍板のフェライト結晶粒 度は Leits 社の映像分析器 (Model TAS-PLUS)によっ て ASTM E112-63 を基準として測定した。

焼鈍板の集合組織を調べるために RIGAKU 社の X線回折装置を用い，逆極点汹を测定した。この際，用い た X-線は Mo- $K_{\alpha}$ の特性 X-線であり，各温度にて焼鈍 された試片を機械研磨と化学研磨を施し $1 / 2$ 厚の位置 に対して板面に平行な $\{110\},\{200\},\{211\}$ および $\{222\}$ 面の X-線積分強度を測定した。

\section{3. 実験結果および考察}

\section{$3 \cdot 1$ 焼鈍温度による機械的性質の変化}

機械的性質におよぼす焼鈍温度の影響を Fig. 1 に示 す。焼鈍温度が高くなるに従って $\bar{r}$ 值が上昇するが, $T S$ と YS は低下する。AI は焼鈍温度に無関係に常に

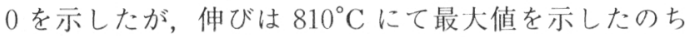
$870^{\circ} \mathrm{C}$ まで減少する段階をへて再び増加する傾向を示し た。佐藤ら ${ }^{5)}$ は炭化物形成元素の $\mathrm{Nb}$ を添加した極低炭 素鋼においては均熱温度が高くなるに従ってフェライト 結晶粒の成長が起こり, 炭化物の溶解が進行するととも にその密度が減少するために伸びの上昇と降伏強度の低 下を惹起するが，炭化物の溶解が顕著に起こる高温領域 では固溶炭素の効果がより強く作用してむしろ伸びの低

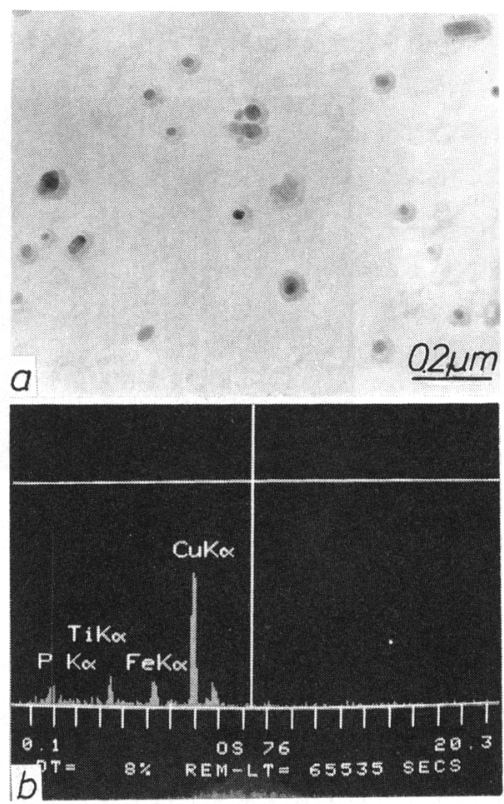

Photo. 1. Transmission electron micrograph of replica with particles extracted in hot band and its energy dispersive $\mathrm{X}$-ray spectra. $\mathrm{Cu} K_{\alpha}$ originates from $\mathrm{Cu}$ mesh. 




Photo. 2. Transmission electron micrographs showing the effect of annealing temperature on the distribution of the precipitaes: a $; 750^{\circ} \mathrm{C}, \quad b ; 780^{\circ} \mathrm{C}, \quad \mathrm{c} ; 810^{\circ} \mathrm{C}, \mathrm{d} ; 840^{\circ} \mathrm{C}$, e; $870^{\circ} \mathrm{C}$ and $\mathrm{f}$; $900^{\circ} \mathrm{C}$. Most precipitates observed in Photo. 2 a through $\mathrm{f}$ reveal energy dispersive $\mathrm{X}$-ray spectra shown in Photo. 2 g.

下と降伏強度の上昇が起こることを報告した。結果的に 仲びと降伏強度がそれぞれ最大值と最小值を示す均熱温 度が存在することになりこのことは上述した相反する効 果に起因することであると説明した。しかしながら，本 研究では前述したように焼鈍温度が上昇するに従って降 伏強度は継続的に低下寸るが，伸びはそれぞれ最大值と
最小值を表す特異な引張特性が観察された。このような 挙動は Nb-P IF 鋼に関する佐藤らの研究の結果 ${ }^{5)}$ とは 大きな差を示す。

一方 Pradhan と MELCheR ${ }^{7)}$ は下降伏強度, $\sigma_{y}$ は $\sigma_{y}=$ $\sigma_{m}+\sigma_{s s}+\sigma_{g s}+\sigma_{p p t}$ の式によって表現できることを報 告した。ここで $\sigma_{m}$ は基地強度 (Matrix strength), $\sigma_{s s}$ 
は固溶強化量 (Solid solution strengthening)， $\sigma_{g s}$ は結 晶粒微細化による強化量 (Grain refinement strengthening), $\sigma_{p p t}$ は析出強化量 (Precipitation strengthening) である. 本研究から得られた焼鈍温度に よる引張性質の挙動も上記の強化方法の組み合わせに よって支配されることと思われ, 以下おのおのの強化機 構について考察する.

一般的に超深絞り用高強度鋼板における強度は固溶強 化能の大きい $\mathrm{P}, \mathrm{Si}$ 抢よび Mn などの置換型固溶元素 による固溶体強化効果として説明されてきた。通常の連 続焼鈍過程にて Mn および $\mathrm{Si}$ は焼鈍温度が変化しても 固溶量の変化はほとんど無いためその強化量には差がな いと思われる。しかし Pは後述するように $(\mathrm{Fe}, \mathrm{Ti}) \mathrm{P}$ としての析出と溶解過程が焼鈍温度によって大きく変化

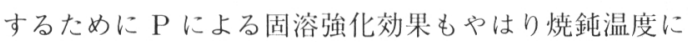
敏感であると同時に ( Fe, Ti $\mathrm{P}$ の析出強化効果に逆比 例することと思われる.

BRuN ら ${ }^{6)}$ は $\mathrm{P}$ と Ti が一緒に多量含有された超深絞 り用高強度鋼板にて卷取り温度が $500^{\circ} \mathrm{C}$ 以下と極めて 低くないかぎり $(\mathrm{Fe}, \mathrm{Ti}) \mathrm{P}$ 形態のりん化物の析出は防 止できないことを報告した。本実験においても $650^{\circ} \mathrm{C}$

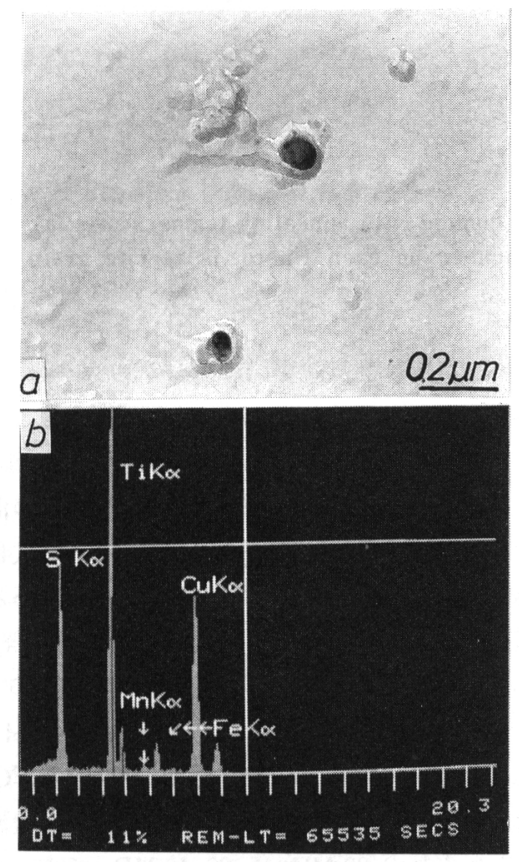

Photo. 3. Transmission electron micrograph of replica with particles extracted in specimen annealed at $900^{\circ} \mathrm{C}$ and its energy dispersive $\mathrm{X}$-ray spectra.
にて巻取りコ程に相当する処理を行った熱延板に多量の 析出物が観察され (Photo. 1 a), この析出物は EDSに より $(\mathrm{Fe}, \mathrm{Ti}) \mathrm{P}$ であることが確認された (Photo. $1 \mathrm{~b})$. Photo. 2 は上記熱延板を冷間压延したのち連続焼鈍し た焼鈍板の焼鈍温度にともなう析出物の分布状態を示し たものである. $810^{\circ} \mathrm{C}$ までの焼鈍温度では高い密度に存 在した析出物が $840^{\circ} \mathrm{C}$ になると急激に溶解し始めて $900^{\circ} \mathrm{C}$ ではその大部分が溶解されたことがわかる。

Photo. 2 で観察される大部分の析出物も EDSにより (Fe，Ti)P と確認され，たまにPhoto. 3 に見られるよ うな $\mathrm{Ti}, \mathrm{Fe}, \mathrm{Mn}$ および $\mathrm{S} の \mathrm{X}$ 線スペクトラムを示す 析出物も存在していた。この $\mathrm{Ti}, \mathrm{Fe}, \mathrm{Mn}$ および $\mathrm{S} の$ $\mathrm{X}$ 線スペクトラムを示す析出物は高温析出物である $\mathrm{Ti}$ 系 Sulfideで, 一部の $\mathrm{Ti}$ のかわりに Fe あるいは Mn が置換されて固溶したもので，熱延板にすでに粗大に析 出していたものが $900^{\circ} \mathrm{C}$ の高温焼鈍でも溶解されず残 存したものと判断される. 本研究では Photo. 2 で観察 される析出物を全部 $(\mathrm{Fe}, \mathrm{Ti}) \mathrm{P}$ と仮定し, これら析出 物による析出強化量を以下の方法より計算した。

GLADMAN ら ${ }^{8)}$ は AshBY ${ }^{9)}$ が修正した Orowan モデルか ら HSLA 鋼の析出強化モデルを導き,このモデルはラ ンダムに分散された析出物の間を転位が湾曲することを 仮定して求めたものである。このモデルを用いて析出物 による析出強化量, $\sigma_{p p t}$ は次のように与えられる.

$$
\sigma_{p p t}(\mathrm{MPa})=(5.9 \sqrt{f} / \bar{x}) \ln \left(\bar{x} / 2.5 \times 10^{-4}\right) \cdots(1)
$$

ここで $\bar{x}$ は析出物の平均直径 $(\mu \mathrm{m}), f$ は析出物の体積 分率である. Photo. 2 から測定した $\bar{x}$ 抢よび $f$ を( 1 ) 式に代人して得られた $\sigma_{p p t}$ を Table 2 に示した。ここ で $\Delta \sigma_{p p t}$ は $780 \sim 900^{\circ} \mathrm{C}$ の焼鈍温度にて計算された析出 強化量と $750^{\circ} \mathrm{C} に て$ 計算された析出強化量との差に相 当する. Photo. 2 と Table 2 から析出物の溶解が顕著 に起こりはじめる温度である $840^{\circ} \mathrm{C} よ り$ 低い温度範囲 では温度上昇にともなう析出強化量の増加が小さいこと がわかりこの温度範囲で $(\mathrm{Fe}, \mathrm{Ti}) \mathrm{P}$ の析出が継続的 に起こっていることを示唆している. しかし $840^{\circ} \mathrm{C}$ 以 上の温度では温度上昇にともなう析出強化量は大幅に減 少している.

Table 2. Calculated values of precipitation strengthening amount with annealing temperature.

\begin{tabular}{c|cccc}
\hline $\begin{array}{c}\text { Annealing } \\
\text { temperature }\left({ }^{\circ} \mathrm{C}\right)\end{array}$ & $\overline{\boldsymbol{x}}(\boldsymbol{\mu m})$ & $f$ & $\sigma_{p p t}(\mathrm{MPa})$ & $\Delta_{\sigma_{p p l}}(\mathrm{MPa})$ \\
\hline 750 & 0.045 & 0.01375 & 78.3 & - \\
780 & 0.040 & 0.01220 & 81.1 & 2.80 \\
810 & 0.046 & 0.01740 & 86.3 & 8.00 \\
840 & 0.054 & 0.00890 & 54.3 & -24.0 \\
870 & 0.075 & 0.00573 & 33.3 & -45.0 \\
900 & 0.094 & 0.00024 & 5.7 & -72.6 \\
\hline
\end{tabular}




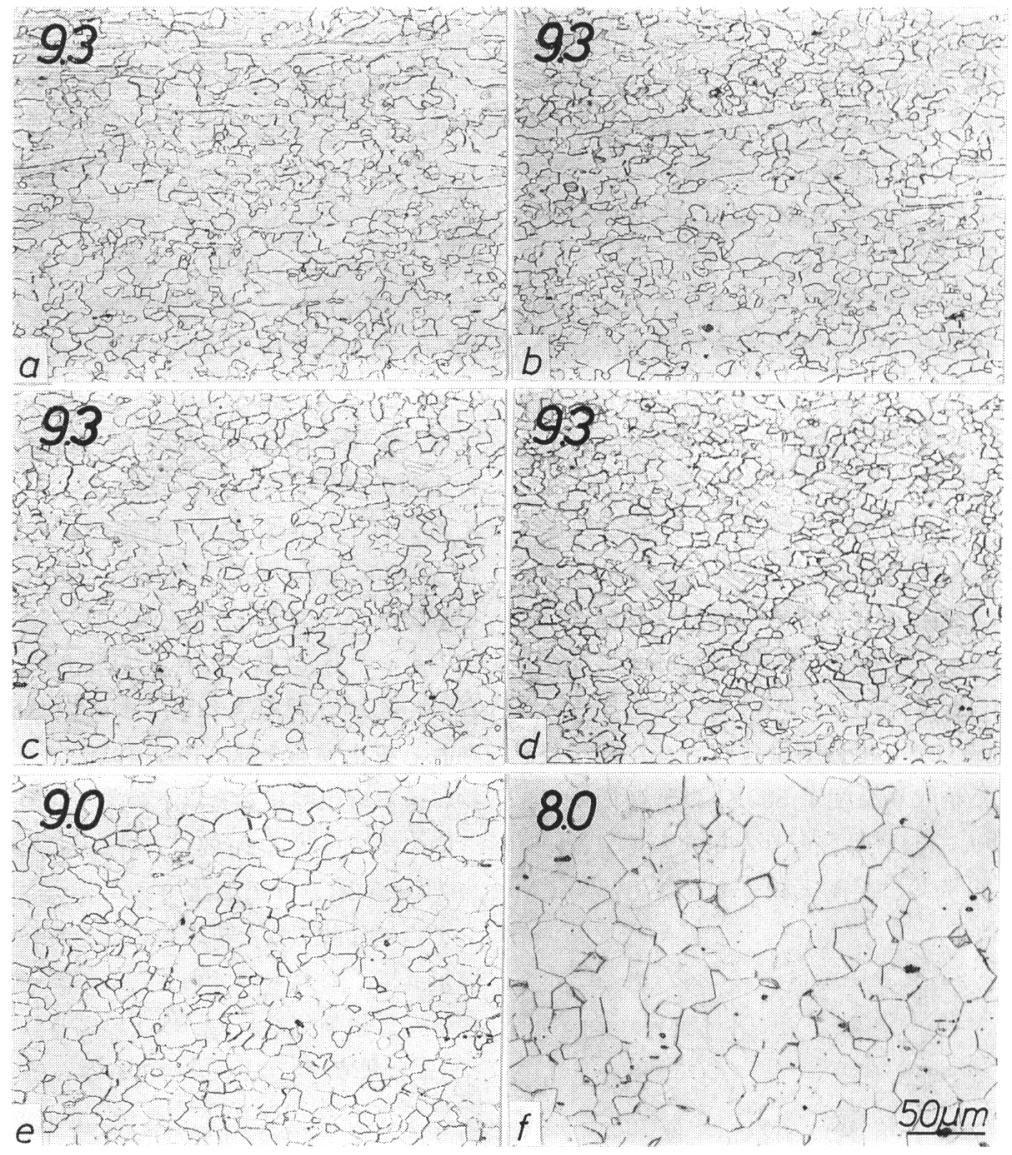

Photo. 4. Optical micrographs showing the microstructural change with annealing temperature : a ; $750^{\circ} \mathrm{C}, \quad b ; 780^{\circ} \mathrm{C}, \quad$ c $; 810^{\circ} \mathrm{C}, \quad d ; 840^{\circ} \mathrm{C}$ and $\mathrm{f} ; 900^{\circ} \mathrm{C}$. Number on each Photo. is ferrite grain size measured by ASTM E112-63.

Photo. 4 は焼鈍温度にともなうフェライト組織の変 化と ASTM E112〜63に従って測定されたフェライト の結晶粒度の变化を示している。焼鈍温度が $750^{\circ} \mathrm{C}$ と 低い場合は再結晶がほぼ完了されつつある段階であるが 若干の変形組織の痕跡が観祭され,このような現象は $780^{\circ} \mathrm{C}$ の焼鈍組織でも残存している。しかし焼鈍温度が $810^{\circ} \mathrm{C}$ 以上になると完全な再結晶が起こってきれいな微 細組織を表し，このような高温にて再結晶が完了される ことは炭空化物形成元素が含まれている鋼で特別に現れ る現象である。 Photo. 4 からわかるもう一つの重要な 結果は $840^{\circ} \mathrm{C}$ までの焼鈍温度ではフェライト結晶粒の 成長が起こらないが $870^{\circ} \mathrm{C}$ 以上に温度が高くなると急 に結晶粒成長が進行するという事実である。この結果は 佐藤ら ${ }^{5)}$ が説明した結晶粒成長による軟化効果が本実験
の場合 $870^{\circ} \mathrm{C}$ 以上の高温ではじめて作用することを意 味する。このようなフェライトの結晶粒成長による強度 減少量, $\Delta \sigma_{g s}$ は次の $(2)$ 式のようにある特定の温度 $T$ でのフェライト結晶粒の大きさを $\mathrm{PETCH}^{10)}$ の式に代人

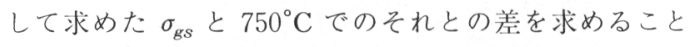
により計算できる

$$
\Delta \sigma_{g S}=k\left(d_{T}^{-1 / 2}-d_{750}^{-1 / 2}\right)
$$

ここで $k$ の值は MORRISON ${ }^{11)}$ による $k=18.14 \mathrm{MPa} /$ $\mathrm{mm}^{-1 / 2}$ を用いた。（2)式から焼鈍温度が $750^{\circ} \mathrm{C}$ から $870^{\circ} \mathrm{C}$ および $900^{\circ} \mathrm{C}$ までの増加にともなう強度減少量 $\Delta \sigma_{g s}$ はそれぞれ $8.29 \mathrm{MPa}$ と $29.40 \mathrm{MPa}$ であった。 以 上で計算された焼鈍温度別 $\sigma_{p p t}, \Delta \sigma_{p p t}, \Delta \sigma_{g s}$ および $\Delta \sigma_{p p t}+\Delta \sigma_{g s}$ の值と引張試験より得られた YS および $\triangle Y S$ を Table 3 に示す。焼鈍温度を $750^{\circ} \mathrm{C}$ から $780^{\circ} \mathrm{C}$ 
Table 3. Comparison between calculated and measured yield strength increment with annealing temperature.

\begin{tabular}{|c|c|c|c|c|c|c|c|}
\hline $\begin{array}{c}\text { Annealing } \\
\text { temperature }\left({ }^{\circ} \mathrm{C}\right)\end{array}$ & $Y S$ & $\triangle Y S$ & $\sigma_{p p l}$ & $\Delta_{\sigma_{p p l}}$ & $\Delta_{\sigma_{g s}}$ & $\Delta_{\sigma_{p p l}}+\Delta_{\sigma_{g s}}$ & $\Delta_{\sigma_{p p t}}+\Delta_{\sigma_{g s}}-\Delta Y S$ \\
\hline 750 & 269.70 & - & 78.3 & - & - & - & - \\
\hline 780 & 252.05 & -17.65 & 81.1 & 2.80 & 0 & 2.80 & 20.45 \\
\hline 810 & 250.09 & -19.61 & 86.3 & 8.00 & 0 & 8.00 & 27.61 \\
\hline 840 & 246.16 & -23.54 & 54.3 & -24.0 & 0 & -24.0 & -0.46 \\
\hline 870 & 225.57 & -44.13 & 33.3 & -45.0 & -8.29 & -53.29 & -9.16 \\
\hline 900 & 196.15 & -73.55 & 5.7 & -72.6 & -29.40 & -102.00 & -28.45 \\
\hline
\end{tabular}

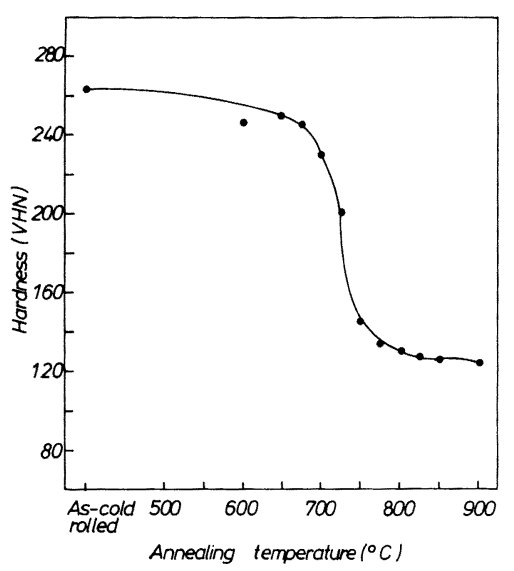

Fig. 2. Hardness variation with annealing temperature.

および $810^{\circ} \mathrm{C}$ に上昇させた時測定された $Y S$ の減少量

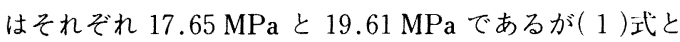
(2)式より計算された $\Delta \sigma_{p p t}$ と $\Delta \sigma_{g s}$ との合計はむしろ $2.80 \mathrm{MPa}$ と $8.0 \mathrm{MPa}$ 増加される結果を示している. このような挙動は $810^{\circ} \mathrm{C}$ 以下の焼鈍温度での降伏強度 に析出強化効果以外の他の強化機構が作用し, 温度の増 加に従って材質を軟化させていることを暗示している. しかし前述したようにこの温度領域では温度が増加して も結晶粒の成長は起こらないのみならず $(\mathrm{Fe}, \mathrm{Ti}) \mathrm{P} の$ 密度も極めて微量に増加する程度であるので, 周溶 $\mathrm{P}$ の減少による効果であると見なすこともむずかしい．こ の現象に対する理由は Photo. 4 と Fig. 2 から探すこと ができると思われる. $750^{\circ} \mathrm{C}$ と $780^{\circ} \mathrm{C}$ で焼鈍された試 料の微細組織は若干の変形組織の痕跡が残っているが, $810^{\circ} \mathrm{C}$ では完全に再結晶された組織を示している. 実際 にはフェライトの結晶粒界による強化効果をとりのぞく

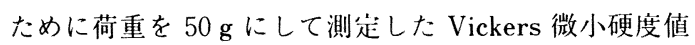
は $750^{\circ} \mathrm{C}$ で 145 を示したが焼鈍温度が $780^{\circ} \mathrm{C}$ および $810^{\circ} \mathrm{C}$ に増加するに従って硬度値はそれぞれ 135 と 128 に減少したことが Fig. 2 からわかる。このような焼鈍 温度にともなう硬度值の減少は再結面の進行による転位 密度の減少に起因するものと思われ，これが $810^{\circ} \mathrm{C}$ 以

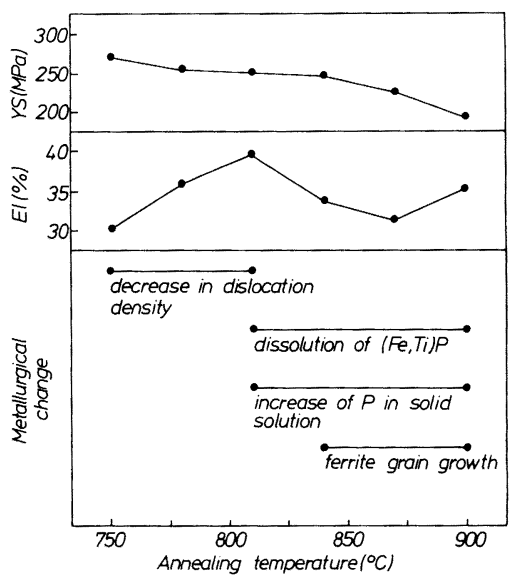

Fig. 3. Metallurgical change with annealing temperature.

下の温度域での温度増加による材質軟化の要因として作 用したと考えられる。庈面 $840^{\circ} \mathrm{C}$ 以上の温度では $\Delta Y S$ の值が $\Delta \sigma_{p p t}$ と $\Delta \sigma_{g s}$ との合計より小さく，この差は焼 鈍温度が上昇するほど増加する。これは $840^{\circ} \mathrm{C}$ 以上の 焼鈍温度で $(\mathrm{Fe}, \mathrm{Ti}) \mathrm{P}$ の溶解が急激に進行し，その結

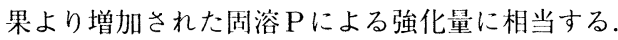

一方，本研究で特異に現れる焼鈍温度にともなう伸び の変化は前述した種々の強化機構が複命的に作用したた めであると思われる，焼鈍温度の变化にともなう強度， 伸びの変化をわかりやすく説明するまとめの润を Fig. 3 に示す. $810^{\circ} \mathrm{C}$ で最大值を示すのは転位密度の減少効果 であり, $870^{\circ} \mathrm{C}$ まで伸びの減少が見られるのは $(\mathrm{Fe}$, Ti) P の溶解による軟化効果と結品粒成長による軟化効 果との合計よりも固溶 $\mathrm{P}$ 量の増加による伸びの劣化程度 が大きいためであると思われる，しかしながら焼鈍温度 が $900^{\circ} \mathrm{C}$ まで達すると再び伸びは増加するが，これは Photo. 4 からわかるようにフェライトの結昆粒成长が 顕著に進行したことに起因したためであると思われる。 しかし焼鈍温度にともなう伸びの変化に対してはもう一 段深い研究が必要と思われる.

$\bar{r}$ 值は焼鈍温度が増加するにともない $840^{\circ} \mathrm{C}$ までゆ るゃかに増加し, それ以上の温度では再び急激に増加す 


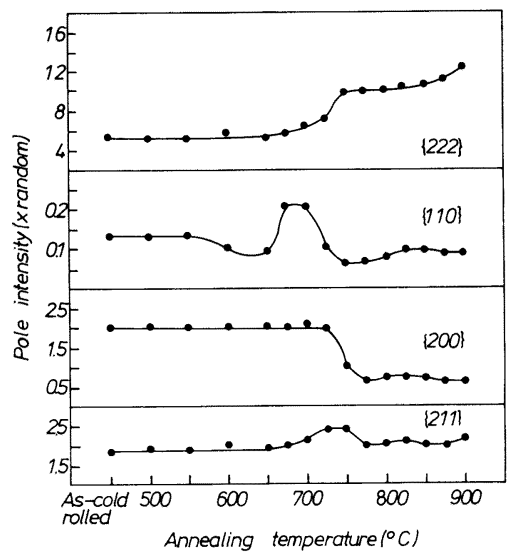

Fig. 4. Effect of annealing temperature on the pole intensity.

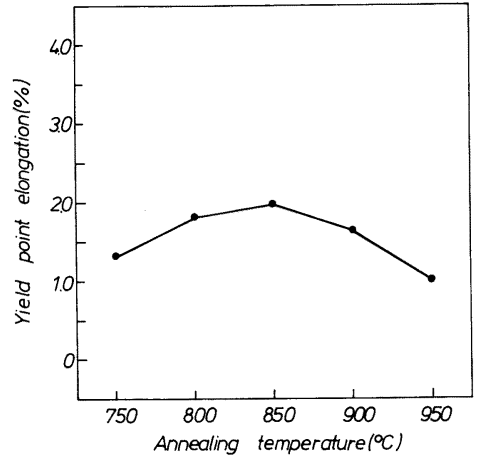

Fig. 5. Variation in yield point elongation with annealing temperature.

る様子を表しこの傾们は Fig. 4 の狫鈍温度にともな う積分強度の変化傾问とよく対忍している。これは薄鋼 板を $\alpha+\gamma$ の相域で焼鈍すると $\{111\}$ 方位のフェラ イト粒が他方位のフェライト粒よりオーステナイトへ変 態しにくいという理論 ${ }^{12)} よ り$ 説明できる.

\section{$3 \cdot 2 \mathrm{Ti}-\mathrm{P}$ 添加超深校り鋼における有効 Ti 量と時効指 数}

$\mathrm{Ti}$ あるいは $\mathrm{Nb}$ などの強力な炭空化物形成元素を添 加した超媣絞り用高強度鋼においては固溶 $\mathrm{C}$ は $\mathrm{Ti}$ や $\mathrm{Nb}$ によって固定されるために IF 鋼あるいは Ti また は $\mathrm{Nb}$ スタビライズド鋼と呼ばれる。 Ti-IF 鋼にてC を 固定するための有効 $\mathrm{Ti}$ 量, $\mathrm{Ti}^{*}$ は通常 $\mathrm{Ti}^{*}=\mathrm{Total}$ $\mathrm{Ti}-(48 / 14) \mathrm{N}-(48 / 32) \mathrm{S}$ の式より示されており ${ }^{13) 14)}$ 本研究にて使用された試料の $\mathrm{Ti}^{*} / \mathrm{C}$ 比を上式より計算 すれば 3.23 であり固溶Cを固走するには十分な量であ ると思われる。しかし焼鈍されたすべての試料は焼鈍温

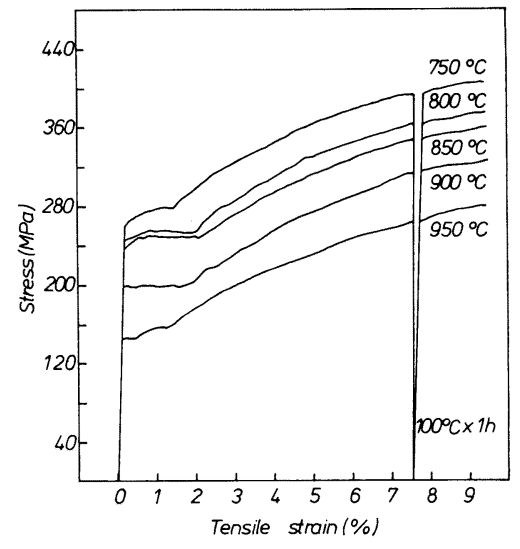

Fig. 6. Typical stress-strain curves with annealing temperature obtained in tensile test for measurement of ageing index.

度と無関係に1〜2\%の降伏点伸び (Yield Point Elongation; YPE) を示していることが Fig. 5 から認め られる。これは固溶 $\mathrm{Cが} \mathrm{Ti}$ によって全量固定されず㹸 鈍值後にも残存することを意味する。このように $\mathrm{Ti}^{*} / \mathrm{C}$ 比が 3.23 でも $1 \sim 2 \%$ のPE が現れるのは $\mathrm{P}$ と Ti が共存するために意起されたと㤁われる. Photo. 1 に示されるように熱延板に多量の $(\mathrm{Fe}, \mathrm{Ti}) \mathrm{P}$ が析出し ており,これら $(\mathrm{Fe}, \mathrm{Ti}) \mathrm{P}$ は $810^{\circ} \mathrm{C}$ 以下の温度での 焼鈍の際もっとも多量に析出したことが Photo. 2 から わかる。このように多量の ( $\mathrm{Fe}, \mathrm{Ti}) \mathrm{P}$ が析出したこと は C を固定するための有効 $\mathrm{Ti}$ 量の隇少を意味し，この ために 3.23 という高い $\mathrm{Ti}^{*} / \mathrm{C}$ 比にもかかわらず $1 \sim 2 \%$ のPE が現れたものと思われる. 实際, 熱延板 と焼鈍板の電子顕微鏡観祭にて Ti-carbide と思われる 析出物は観祭されなかった。 従ってPと Ti が多量に共 存する鋼に执ける有効 $\mathrm{Ti}$ 量は $(\mathrm{Fe}, \mathrm{Ti}) \mathrm{P}$ の析出を考 慮して

$$
\begin{aligned}
\mathrm{Ti}^{* *} & =\text { Total } \mathrm{Ti}-(48 / 14) \mathrm{N}-(48 / 32) \mathrm{S} \\
& -\mathrm{Ti} \text { as }(\mathrm{Fe}, \mathrm{Ti}) \mathrm{P} \ldots \ldots \ldots \ldots \ldots \ldots \ldots \ldots \ldots \ldots \ldots \ldots \ldots \ldots \ldots \ldots
\end{aligned}
$$

式で表したほうが合理的であろうと思われる。このよう な $(\mathrm{Fe}, \mathrm{Ti}) \mathrm{P}$ の析出により有効 $\mathrm{Ti}$ 量が減少し,これ により固溶Cが残存することは Ti-P IF 鋼の $\bar{r}$ 值へも 影響を与えると考えられる.

反面，焼鈍状態で 1 2\%の YPE が現れたにもかか わらず $7.5 \%$ の予歪みを加えた後 $100^{\circ} \mathrm{C} て ゙ ~ 1 \mathrm{~h}$ 人 1 時 効させてから測定した $A I$ は焼鈍温度と無関係に常に零 であった。 その典型的な心力-歪み曲線を Fig. 6 に示し

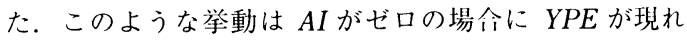
ないという従来の研究結果とは大きな差を示している. 
これは 1 2\%の YPEに比べ付加された予歪みが $7.5 \%$ で大きいために $7.5 \%$ の予歪みによって新しく生ずる可 動転位の数が $1 \sim 2 \%$ の YPE に相当する固溶 C量に比 べ多くなったことに起因されると思われる.

\section{4. 結言}

$\mathrm{P}$ と Ti を添加した極低炭素冷延鋼板の機械的性質の 焼鈍温度依存性を調べた結果，次のことが明らかになっ た.

1 ) 今までは炭窣化物形成元素を添加した極低炭素冷 延鋼板の焼鈍温度の上昇にともなう機械的性質の変化は フェライト結晶粒の成長効果と炭化物の溶解および炭化 物の溶解による固溶 $\mathrm{C}$ 量の増加によって説明されてきた が, 本研究では転位強化, $\mathrm{P}$ による固溶強化, $(\mathrm{Fe}, \mathrm{Ti}) \mathrm{P}$ の析出による析出強化およびフェライト結晶粒成長効果 などの四つの強化機構が各温度領域で単独または複合的 に作用することによるものと考えられる.

2) $750^{\circ} \mathrm{C} \sim 810^{\circ} \mathrm{C}$ の温度範囲にて $30 \mathrm{~s}$ 連続焼鈍した 冷延鋼板に存在する $(\mathrm{Fe}, \mathrm{Ti}) \mathrm{P}$ の析出物による析出強 化量を Ashby-Orowan モデルから計算した結果，その 大きさは約 $80 \mathrm{MPa}$ 程度で非常に大きい強化効果を表し た.

3) $\mathrm{P}$ と $\mathrm{Ti}$ を共に含有した極低炭素冷延鋼板の有効 $\mathrm{Ti}$ 量は $(\mathrm{Fe}, \mathrm{Ti}) \mathrm{P} と し て$ 析出される $\mathrm{Ti}$ 量を考慮して
$\mathrm{Ti}^{* *}=$ Total $\mathrm{Ti}-(48 / 14) \mathrm{N}-(48 / 32) \mathrm{S}-\mathrm{Ti}$ as $(\mathrm{Fe}$, $\mathrm{Ti}) \mathrm{P}$ で表すのが合理的であろうと考えられる.

\section{文献}

1 ) 秋末 治, 山田輝昭, 上田 茂, 高階喜久男: 鉄と䤡, 68 (1982), p. 1388

2) 下村隆良, 小野 賢, 大沢紘一, 松藤和雄: 同上, p. 1228

3 ) 岡本篤樹, 高橋政吕], 日野貴大, 中居修二: 同上, p. 1369

4 ) 野村伸吾, 宮原征行, 柚鳥善之, 亀野克己, 川本国雄, 小久保一郎: 同上, p. 1284

5 ) 佐藤 進, 入江敏大, 橋本 修: 同上, p. 1362

6 ) C. Brun, P. Patou and P. Parniere: Metallurgy of Continuous-Annealed Sheet Steel, ed. by B. L. BramfitT and P. L. MANGonon, Jr., TMS-AIME, Warrendale, PA (1982), p. 173

7 ) R. R. Pradhan and E. D. Mrlcher: Mechanical Working and Steel Processing XVIII, Iron and Steel Society of AIME, Warrendale, PA (1980), p. 34

8 ) T. Gl.adman, D. Dalieu and I. D. McIvor: Microalloying 75 (1976), p. 32 [Union Carbide Corp., New York]

9 ) M. F. AsHry: Oxide Dispersion Strengthening, AIME, Warrendale, PA (1966), p. 61

10) N. J. PетсH: J. Iron Steel Inst., 173 (1953), p. 25

11) W. E. MorRISON: Trans. Am. Soc. Met., 59 (1966), p. 824

12）橋本 修, 佐藤 進, 田中智夫: 鉄と鋼, 67 (1981), p. 799

13) T. IRIE, S. SATOH, $A$. Yasuda and $O$. HaShimoto: Metallurgy of Continuous-Annealed Sheet Steel, ed. by B. L. Bramfitt and P. L. Mangonon, Jr., TMS-AIME, Warrendale, PA (1982), p. 155

14) S. SAToH, $T$. Obara, M. NiShidA and T. IrIE: Technology of Continuously Annealed Cold-Rolled Sheet Steel, ed. by $R$. Pradhan, TMS-AIME, Warrendale, PA (1984), p. 151 